\title{
Isolation and Inheritance of Microsatellite Markers in the Common Carp Cyprinus carpio
}

\author{
Ratu Siti Aliah, ${ }^{* 1}$ Motohiro Takagi, ${ }^{* 2}$ Shi Dong, ${ }^{* 1}$ \\ Chin Tick Teoh, ${ }^{* 1}$ and Nobuhiko Taniguchi ${ }^{* 1, \dagger}$ \\ *1Department of Aquaculture, Faculty of Agriculture, Kochi University, Monobe, \\ Nankoku, Kochi 783-8502, Japan \\ ${ }^{* 2}$ Limnological Station, National Fisheries University, Ooaza Ono, Ube, \\ Yamaguchi 754-1311, Japan
}

(Received August 3, 1998)

\begin{abstract}
Three microsatellite loci, $C c a-17^{*}, C c a-21^{*}$, and $C c a-30^{*}$, were isolated from a partial genome library of common carp Cyprinus carpio. Primers for PCR amplification of template DNA were designed based on the unique sequences flanking each motif. The total number of alleles detected from nishikigoi and wild type common carp population were five, six and nine at loci $\mathrm{Cca}-17^{*}, \mathrm{Cca}-21^{*}$, and $\mathrm{Cca}-30^{*}$, respectively. Inheritance was shown to be Mendelian by analysis of genotype ratio in $\mathrm{F} 1$ offspring of six families of nishikigoi. Allele ${ }^{*} 69$ at locus $\mathrm{Cca}-21^{*}$ and allele ${ }^{*} 266$ at locus $\mathrm{Cca}-30^{*}$ were detected only in wild type common carp with frequencies of 0.304 and 0.458 , respectively, while allele *288 was observed only in the nishikigoi with the frequencies ranged from $0.600-0.610$.
\end{abstract}

Key words: Common carp, Cyprinus carpio, microsatellite DNA, Mendelian inheritance

Isozyme polymorphism has been used effectively as a genetic marker to characterize the population structure of various fish species. However, highly polymorphic markers are needed to detect the inbreeding in aquacultural stocks, in pedigree analysis and in the study of breeding success in wild populations. At the levels of individual, sub population and population, the investigation of variable number tandem repeat loci (VNTRs) using multi-locus and single locus DNA fingerprinting showed a high level of polymorphism. However, these methods have limited application due to technical difficulties in interpreting the results. ${ }^{1)}$

More recently microsatellites or simple sequence repeats, which consist of short tandemly arrayed di-, tri- or tetranucleotide sequences, flanked on either side by regions of unique DNA, ${ }^{2)}$ have been shown to be highly polymorphic in fish. ${ }^{3)}$ Primers synthesized complementary to these flanking sequences may amplify alleles at microsatellite loci by the PCR. Size of alleles can be accurately determined by electrophoresis on polyacrylamid gel. Due to the relatively high polymorphism, microsatellite loci may be used as a markers in studies of population genetics, pedigree analysis and phylogeny. ${ }^{4)}$ To date, microsatellite markers in fish have been effectively used in population study, ${ }^{3,5-8)}$ parentage and kinship analysis. ${ }^{9-11)}$

In this study we report the isolation of microsatellite loci from the genome of common carp Cyprinus carpio. Primers were designed for three loci and their amplification conditions were optimized. After analysing the Mendelian inheritance in nishikigoi, the Japanese ornamental (koi) carp, the level of polymorphism of the three markers was examined in nishikigoi and the wild type of common carp.

\section{Materials and Methods}

\section{Fish Samples and DNA Extraction}

Six families of nishikigoi were produced in our laboratory and used for analysis of the Mendelian inheritance. According to Japanese classification, ${ }^{12}$ they were consisted of 1 family of kouhaku (white fish with red patches), 2 families of hybrid kouhaku and showa sanke (black fish with red and white patches) and a family of either tancho (white fish with one red circled patch on the head), taisho sanke (white fish with red and black patches) or showa sanke type (Table 1). These parent fish and their offspring (20-22 individuals / family), together with the wild type of common carp population collected from Shimanto River, Nakamura City, Kochi Prefecture, were analyzed for microsatellite loci polymorphism and their genetic variability.

DNA samples were extracted from a fin clip of each individual by standard SDS-phenol/chloroform procedures ${ }^{13)}$ and stored at $4{ }^{\circ} \mathrm{C}$ prior to $\mathrm{PCR}$ amplification.

Table 1. Description of the six families of nishikigoi studied

\begin{tabular}{cll}
\hline \multirow{2}{*}{ Family } & \multicolumn{2}{c}{ Parental } \\
\cline { 2 - 3 } & \multicolumn{1}{c}{ Female } & \multicolumn{1}{c}{ Male } \\
\hline 1 & Kouhaku & Kouhaku \\
2 & Tancho & Tancho \\
3 & Taisho sanke & Taisho sanke \\
4 & Showa sanke & Showa sanke* \\
5 & Kouhaku & Showa sanke* \\
6 & Kouhaku & Showa sanke* \\
\hline
\end{tabular}

* same individual.

\footnotetext{
${ }^{\dagger}$ Corresponding author.
} 


\section{Cloning and Sequencing of Microsatellite}

For cloning purposes, genomic DNA was extracted from pooled blood sample of five mixed sex common carp and nishikigoi individuals belonging to either matsubaoogon (golden metallic with a reticulated net-like pattern), kouhaku or sanke type. Positive clones were screened with $(G T)_{15}$ synthetic oligonucleotide and sequenced, and primers were designed for the unique flanking sequences following the protocols described by Takagi et al. ${ }^{14)}$

\section{Microsatellite Polymorphism}

The reverse primer was $5^{\prime}$ end labeled with $\left[\gamma^{32} \mathrm{P}\right] \mathrm{ATP}$. PCR was carried out using an MJ Thermal cycler. The $5 \mu l$ of reaction contained $15 \mathrm{ng}$ of template DNA, $0.20 \mu \mathrm{M}$ each unlabelled primer, $0.02 \mu \mathrm{M}$ labeled reverse primer, $10 \mathrm{~mm}$ of Tris-HCL (pH 8.3), $1 \mathrm{mM} \mathrm{MgCl}_{2}, 50 \mathrm{mM} \mathrm{KCl}$, $0.01 \%$ gelatin, $0.20 \mathrm{mM}$ each dNTPs and 0.12 unit of Taq polymerase (TaKaRa). The PCR was programmed for $7 \mathrm{cy}-$ cles consisting of denaturation for $1 \mathrm{~min}$ at $94^{\circ} \mathrm{C}$, annealing for $30 \mathrm{~s}$ at the appropriate temperature (Table 2), and extention for $30 \mathrm{~s}$ at $72^{\circ} \mathrm{C}$, followed by 30 cycles consisting of denaturation for $30 \mathrm{~s}$ at $90^{\circ} \mathrm{C}$, annealing for $30 \mathrm{~s}$ at annealing temperature, extention for $30 \mathrm{~s}$ at $72^{\circ} \mathrm{C}$. Following amplification the samples were mixed with an equal volume of denaturing stop dye (Pharmacia), heated for 15 min at $95^{\circ} \mathrm{C}$, electrophoresed on $8 \%$ polyacrylamide gel ( $7 \mathrm{M}$ urea, $8 \%$ acrylamide), dried and finally exposed to autoradiography film (Fuji RX-U). Microsatellite alleles were sized relative to a $M 13$ sequence ladder.

\section{Mendelian Inheritance of Microsatellite Loci}

The microsatellite loci previously identified were scored in parents and offspring. Genotype ratios of the offspring were tested for conformance with Mendelian expectations using $\chi^{2}$ test. The symbols of locus, allele, phenotypes and genotypes were written based on Shaklee et al. ${ }^{15)}$ The loci were designated by the number of the colony isolated, while the alleles were designated by molecular size of the amplified fragments relative to a M13 sequence ladder.

\section{Results}

Detection of Microsatellite Loci and Their Polymorphism

Among a total of 30 microsatellites isolated from a partial genomic library of common carp, clear amplification and scorable variation were observed in 3 microsatellites$\mathrm{Cca}-17^{*}, \mathrm{Cca}-21^{*}$, and $\mathrm{Cca}-30^{*}$. Two of them were perfect motifs $\left[(T)_{25}\right.$ and $\left.(G T)_{11}\right]$, and one was a compound motif $\left[(\mathrm{GT})_{18}+(\mathrm{GA})_{20}\right]$. The primer sequences, annealing temperature, number of alleles, amplified product size range, and heterozygosities for the three loci are shown in Table 2. Based on data obtained from 34 samples, five alleles were observed at the locus $\mathrm{Cca}-17^{*}$, six alleles at $\mathrm{Cca}-2 \mathrm{l}^{*}$, and nine alleles at $\mathrm{Cca}-30^{*}$. The length of alleles ranged from 179 to $199 \mathrm{bp}$ for $\mathrm{Cca}-17^{*}$, from 69 to $81 \mathrm{bp}$ for $\mathrm{Cca}-2 I^{*}$ and from 260 to $318 \mathrm{bp}$ for $\mathrm{Cca}-30^{*}$.

\section{Mendelian Inheritance of Microsatellite Loci}

Genotypic frequencies of parents and offspring are shown in Table 3 and Fig. 1. At locus $\mathrm{Cca}-17^{*}$, all parent fish were homozygote and gave all homozygote offspring. At $C c a-21^{*}, 5$ out of 6 families had a heterozygous parent, and the proportion of homozygote and heterozygote offspring was not significantly different from the 1:1 Mendelian ratio. Male and female parents of family 4 were homozygotes at alternative alleles and gave all heterozygous offspring as expected. At the locus $\mathrm{Cca}-30^{*}$, both parents of family 1 were heterozygous $\left({ }^{*} 288 / 300\right.$ and ${ }^{*} 288$ / 318 ) and shared only one alleles, therefore giving an expected ratio of $1: 1: 1: 1$ of homo- and heterozygotes, and this result did agree with the expectation. Four families had both parents possessing the same heterozygous genotype and gave genotype not statistically different with a ratio of $1: 2: 1$ in the offspring. Family 4 had a parent possessing heterozygous genotype thus gave an offspring genotype ratio not significantly different from $1: 1$.

\section{Genetic Variation}

At the $\mathrm{Cca}-17^{*}$ locus, only one allele $\left({ }^{*} 185\right)$ was observed in parent nishikigoi, while a total of 5 alleles including allele ${ }^{*} 185$ were found in the wild type (Table 4). Allele * 185 was a common allele among wild type, with a frequency of 0.562 . At the locus $C c a-21^{*}, 3$ alleles found in nishikigoi $\left({ }^{*} 75, * 77\right.$, and $\left.* 79\right)$ were similar to those found in the wild type, in which a total of 6 alleles were observed. However, the two groups were dominated with different alleles, allele $* 79$ (frequency $=0.550$ ) in nishikigoi and allele ${ }^{*} 69$ (frequency $=0.301$ ) in the wild type. At the locus $C c a-$ $30^{*}$, only one allele was shared between the two groups (allele $\left.{ }^{*} 300\right)$ with low gene frequency $(0.050$ in nishikigo $i$ and 0.043 in the wild type). Three alleles $\left({ }^{*} 288,{ }^{*} 300\right.$, and ${ }^{*} 318$ ) were found in nishikigoi, while 7 alleles $\left(* 260,{ }^{*} 262\right.$, ${ }^{*} 266,{ }^{*} 268, * 292, * 296$, and ${ }^{*} 300$ ) were observed in the wild type. The mean observed heterozygosity of three loci

Table 2. Nucleotide sequence of common carp microsatellites and primers for amplification of loci by PCR

\begin{tabular}{|c|c|c|c|c|c|}
\hline Locus & & Sequence $5^{\prime} \rightarrow 3^{\prime}$ & $\begin{array}{c}\text { Annealing } \\
\text { temperature }\left({ }^{\circ} \mathrm{C}\right)\end{array}$ & No. of alleles & $\begin{array}{l}\text { Size } \\
(\mathrm{bp})\end{array}$ \\
\hline \multirow[t]{3}{*}{$\mathrm{Cca}-17^{*}$} & & $(\mathrm{~T})_{25}$ & & & \\
\hline & $\mathrm{F}^{*}$ & CAACACATAACCGCATTTCT & 47 & 5 & $179-199$ \\
\hline & $\mathrm{R}^{* 2}$ & CTTTCTTGTGATTGACCTCC & & 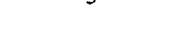 & \\
\hline \multirow[t]{3}{*}{ Cca-2 $21^{*}$} & & $(\mathrm{GT})_{11}$ & & & \\
\hline & $\mathrm{F}$ & AAGGTGAGTGTGACGACGG & 53 & 6 & $69-81$ \\
\hline & $\mathrm{R}$ & AGCACAAACACACGGTCAG & & & \\
\hline \multirow[t]{3}{*}{$\mathrm{Cca}-30^{*}$} & & $(\mathrm{GT})_{18}+(\mathrm{GA})_{20}$ & & & \\
\hline & $\mathrm{F}$ & СТGCСТTCTTCTACTCTACAC & 50 & 9 & $260-318$ \\
\hline & $\mathrm{R}$ & TTGCCTCTATGCTTGATTTT & & & \\
\hline
\end{tabular}

\footnotetext{
*1 Forward primer
}

*2 Reverse primer. 
Table 3. Genotypes of parents and offspring of nishikigoi at 3 microsatellite loci

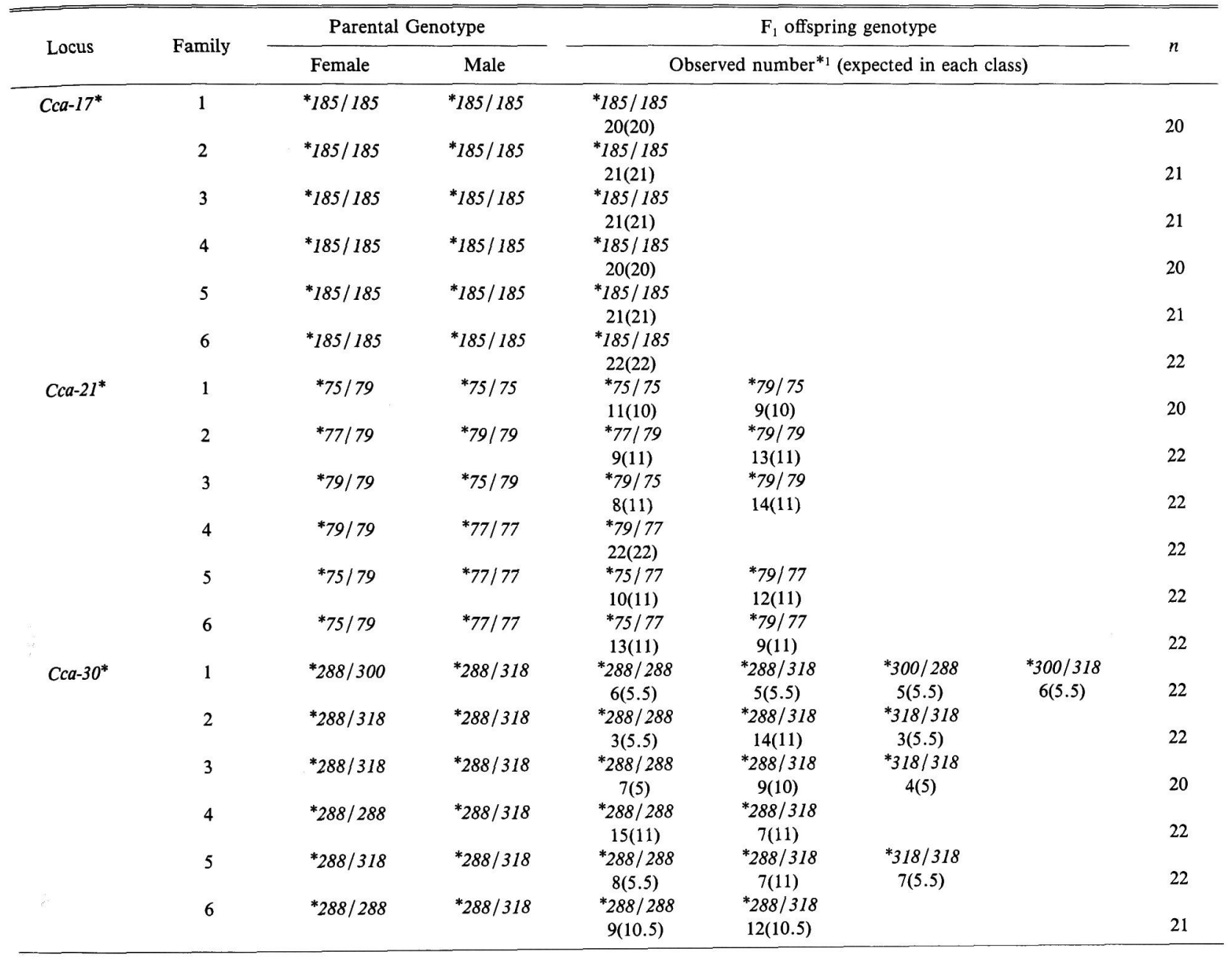

${ }^{*}{ }_{1}$ Non significant at $P<0.05$.

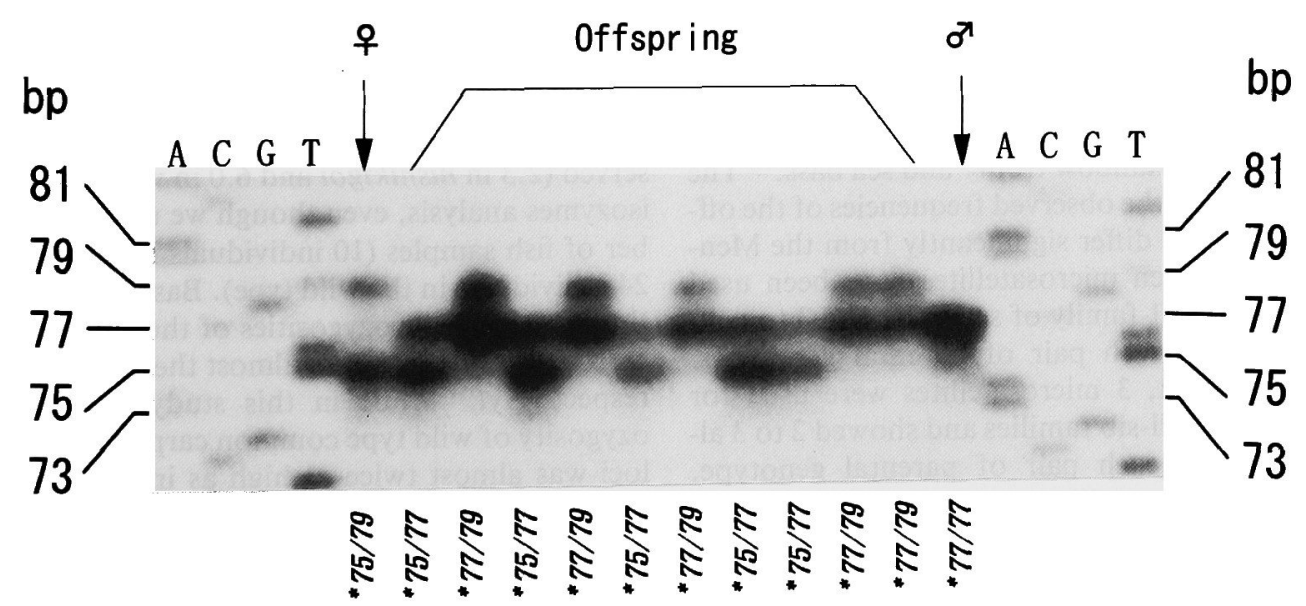

Fig. 1. Microsatellite alleles of nishikigoi and its $\mathrm{F}_{1}$ offspring at locus Cca-21* (lane 1: female parent, lane 2-11: $\mathrm{F}_{1}$ offspring, lane 12: male parent). The size standard is a sequencing ladder of M13 $\mathrm{mp} 18$. 
Table 4. Allele frequency of three microsatellite loci in parent stock of nishikigoi, $\mathrm{F}_{1}$ offspring of nishikigoi and the wild type of common carp

\begin{tabular}{|c|c|c|c|c|c|c|c|c|c|c|c|}
\hline \multirow{2}{*}{ Allele } & \multicolumn{3}{|c|}{$\operatorname{Cog}-17^{*}$} & \multirow[b]{2}{*}{ Allele } & \multicolumn{3}{|c|}{$C c a-21^{*}$} & \multirow{2}{*}{ Allele } & \multicolumn{3}{|c|}{$C c a-30^{*}$} \\
\hline & Parent & $\begin{array}{c}\mathrm{F}_{1} \\
\text { offspring }\end{array}$ & Wild type & & Parent & $\begin{array}{c}\mathrm{F}_{\mathrm{I}} \\
\text { offspring }\end{array}$ & Wild type & & Parent & $\begin{array}{c}\mathrm{F}_{1} \\
\text { offspring }\end{array}$ & Wild type \\
\hline No. of fish & 10 & 130 & 24 & & 10 & 130 & 24 & & 10 & 129 & 24 \\
\hline${ }^{*} 179$ & - & - & 0.188 & $* 69$ & - & - & 0.304 & $* 260$ & - & - & 0.250 \\
\hline$* 181$ & - & - & 0.062 & $* 71$ & - & - & 0.196 & $* 262$ & - & - & 0.062 \\
\hline${ }^{*} 185$ & 1.000 & 1.000 & 0.562 & $* 75$ & 0.300 & 0.238 & 0.218 & ${ }^{*} 266$ & - & - & 0.458 \\
\hline$* 197$ & - & - & 0.021 & $* 77$ & 0.150 & 0.288 & 0.043 & $* 268$ & - & - & 0.021 \\
\hline \multirow[t]{5}{*}{${ }^{*} 199$} & - & - & 0.167 & $* 79$ & 0.550 & 0.474 & 0.043 & ${ }^{*} 272$ & - & - & 0.125 \\
\hline & & & & $* 81$ & - & - & 0.196 & $* 276$ & - & - & 0.042 \\
\hline & & & & & & & & ${ }^{*} 288$ & 0.600 & 0.610 & - \\
\hline & & & & & & & & $* 300$ & 0.050 & 0.044 & 0.042 \\
\hline & & & & & & & & $* 318$ & 0.350 & 0.346 & - \\
\hline
\end{tabular}

Table 5. Genetic variability of three microsatellite loci of nishikigoi and the wild type of common carp

\begin{tabular}{|c|c|c|c|c|c|c|}
\hline & & & $\mathrm{Cca}-17^{*}$ & $\operatorname{Cca}-2 I^{*}$ & $\operatorname{cca}-30^{*}$ & $\frac{\text { Mean }}{\text { (within population) }}$ \\
\hline \multirow{10}{*}{$\begin{array}{l}\text { Crossbreeding } \\
\text { experiment of } \\
\text { nishikigoi }\end{array}$} & \multirow[t]{5}{*}{ Parent stock } & No, of sample & 10 & 10 & 10 & \\
\hline & & No. of allele & 1 & 3 & 3 & 2.3 \\
\hline & & Heterozygosity (Ho) & 0 & 0.556 & 0.889 & 0.482 \\
\hline & & $(\mathrm{He})$ & 0 & 0.650 & 0.572 & 0.407 \\
\hline & & (Ho/He) & - & 0.855 & 1.554 & 1.184 \\
\hline & \multirow[t]{5}{*}{ Offspring } & No. of sample & 125 & 130 & 127 & \\
\hline & & No. of allele & 1 & 3 & 3 & 2.3 \\
\hline & & Heterozygosity (Ho) & 0 & 0.906 & 0.472 & 0.459 \\
\hline & & $(\mathrm{He})$ & 0 & 0.707 & 0.562 & 0.423 \\
\hline & & $(\mathrm{Ho} / \mathrm{He})$ & - & 1.282 & 0.840 & 1.085 \\
\hline \multirow{5}{*}{$\begin{array}{l}\text { Wild type of } \\
\text { common carp }\end{array}$} & & No. of sample & 24 & 23 & 24 & \\
\hline & & No. of allele & 5 & 6 & 7 & 6.0 \\
\hline & & Heterozygosity (Ho) & 0.694 & 1.014 & 1.064 & 0.924 \\
\hline & & $(\mathrm{He})$ & 0.684 & 0.867 & 0.782 & 0.778 \\
\hline & & (Ho/He) & 1.015 & 1.170 & 1.361 & 1.188 \\
\hline
\end{tabular}

in wild type was 0.924 , twice as high as in the nishikigoi parent (0.482) and offspring (0.459) (Table 5).

\section{Discussion}

Two loci, $C c a-21^{*}$ and $C c a-30^{*}$, have been shown to follow the Mendelian inheritance in 6 families of nishikigoi. Two to three alleles were detected in each pair of parental genotype. A microsatellite marker has also been applied for pedigree analysis in rainbow trout" and sea bass. ${ }^{\text {(1) }}$ The results also showed that the observed frequencies of the offspring genotype did not differ significantly from the Mendelian expectation. Seven microsatellites have been used for pedigree analysis in 1 family of sea bass, and 3 to 4 alleles were detected in each pair of parental genotypes. While in rainbow trout, 3 microsatellites were used for pedigree analysis in 3 full-sib families and showed 2 to 3 alleles were detected in each pair of parental genotype. Therefore, since a microsatellite marker has detected two or more alleles in one pair of parental genotype, it can be used as a marker for pedigree analysis.

Genetic study on qualitative and quantitative traits of the European common carp is well established. ${ }^{16)}$ Furthermore, biochemical marker studies also have been carried out in Chinese, European, Japanese and Indonesian common carp. ${ }^{17-19)}$ This study of microsatellite DNA markers shows that the variability observed in microsatellite loci was higher than that of isozymes in the wild type of common carp and nishikigoi. Sumantadinata and Taniguch ${ }^{197}$ has identified 23 gene loci encoding 11 enzymes and protein systems from 167 fish samples (4 lots) of both nishikigoi and the wild type of common carp stock and found an average of 1.261 alleles per locus in nishikigoi and 1.171 alleles per locus in wild type. Using microsatellite DNA, a larger number of alleles per locus were observed (2.3 in nishikigo $i$ and 6.0 in wild type) than through isozymes analysis, even though we used only a small number of fish samples (10 individuals in the parent stock and 24 individuals in the wild type). Based on the isozyme loci, the observed heterozygosities of the wild type of common carp and nishikigoi were almost the same, 0.042 and 0.047 respectively, ${ }^{19)}$ while in this study, the observed heterozygosity of wild type common carp at microsatellite DNA loci was almost twice as high as in nishikigoi, 0.924 and 0.482 respectively. Genetic variability was also observed in the natural and hatchery populations of red sea bream using isozymes and microsatellite DNA markers. ${ }^{20)}$ No distinct difference was found in the average heterozygosity between the natural population and hatchery population of red sea bream based on isozyme data, while using microsatellite DNA the apparent reduction of the average heterozygosity of hatchery population was observed. 
These results were similar to those found in the wild type population of common carp and nishikigoi. However, the observed heterozygosity in the wild type of common carp $(0.924)$ was higher than that of the natural population of red sea bream $(0.810)^{14)}$ although the smaller number of alleles per locus was detected in common carp compared to those of red sea bream, 6.0 and 22.4 alleles per locus respectively.

This study demonstrated the usefulness of microsatellite DNA marker for pedigree analysis in nishikigoi and detection of genetic variability in both the wild type of common carp and nishikigoi. Only 2 loci were successfully used for pedigree analysis; thus more polymorphic loci must be isolated.

\section{References}

1) M. Lynch: Analysis of population genetic structure by DNA fingerprinting, in "DNA Fingerprinting: Approaches and Applications" (ed. by T. Burke, G. Dolft, A. J. Jeffrey, and R. Wolff), Birkhauser Verlag, Basel, Switzerland, 1991, pp. 113-126.

2) D. Tautz: Hyperiability of simple sequence as a general source of polymorphic DNA markers. Nucleic. Acid Res., 17, 6463-6471 (1989).

3) A. L. Brooker, D. Cook, P. Bentzen, J. M. Wright, and R. W. Doyle: Organization of microsateilites differs between mammals and cold-water teleost fishes. Can. J. Fish. Aquat. Sci., 51, 19591966 (1994).

4) L. K. Park and P. Moran: Developments in molecular genetic techniques in fisheries, in "Molecular Genetics in Fisheries" (ed. by G. R Carvalho, and T. J. Pitcher), Chapman and Hall, London, 1995, pp. 1-28.

5) B. Angers, L. Bernatchez, A. Angers, and L. Desgroseillers: Specific microsatellite loci for brook charr reveal strong population subdivision on a microgeographic scale. J. Fish Biol., 47 (Suppl. A), 177-185 (1995).

6) S. McConnell, L. Hamilton, D. Morris, D. Cook, D. Paquet, P. Bentzen, and J. Wright: Isolation of salmonid microsatellite loci and their application to the population genetics of Canadian east coast stocks of Atlantic salmon. Aquaculture, 137, 19-30 (1995).

7) S. K. McConnell, P. O'Reilly, L. Hamilton, J. M. Wright, and P. Bentzen: Polymorphic microsatellite loci from Atlantic salmon
(Salmo salar): genetic differentiation of North American and European populations. Can. J. Fish. Aquat. Sci., 52, 1863-1872 (1995).

8) D. B. Morris, K.R. Richard, and J. M. Wright: Microsatellites from rainbow trout (Oncorhynchus mykiss) and their use for genetic study of salmonids. Can. J. Fish. Aquat. Sci., 53, 120-126 (1996).

9) A. Estoup, P. Presa, F. Kreig, D. Vaiman, and R. Guyomard: (CT) $\mathrm{n}$ and (GT)n microsatellites: a new class of genetic markers for Salmo trutta L. (brown trout). Heredity, 71, 488-496 (1993).

10) H. I. Kincaid: An evaluation of inbreeding and effective population size in salmonid broodstocks in federal and state hatcheries. American Fisheries Society Symposium, 15, 193-204 (1995).

11) F. J. Garcia de Leon, B. Chatain, M. Canonne, J. J. Versini, and F. Bonhomme: Development and use of microsatellite markers in sea bass, Dicentrarchus labrax (Linnaeus, 1758) (Perciformes: Serrandidae). Mol. Mar. Biol. and Biotech., 4, 62-68 (1995).

12) M. Tamadachi: The cult of the koi. Second edition, Expanded, $T$. F. H. Publication, Inc. Neptune City, 1994. 320 p.

13) A. S. Harris, S. Bieger, R. W. Doyle, and J. M. Wright: DNA fingerprinting of tilapia, Oreochromis niloticus, and its application to aquaculture genetics. Aquaculture, 92, 157-163 (1991).

14) M. Takagi, N. Taniguchi, D. Cook, and R. W. Doyle: Isolation and characterization of microsatellite loci from red sea bream Pagrus major and detection in closely related species. Fisheries Sci., 63, 199-204 (1997).

15) J. B. Shaklee, F. W. Allendorf, D. C. Morizot, and G. S. Whitt: Gene nomenclature for protein-coding loci in fish. Transactions of the American Fisheries Society, 119, 2-15 (1990).

16) V. S Kirpichnikov: Genetic Bases of Fish Selection, SpringerVerlag, Berlin, 1981, $410 \mathrm{p}$.

17) T. Brody, D. Kirsht, G. Parag, G. Wolfarth, G. Hulata, and R. Moav: Biochemical genetic comparison of the Chinese and European races of the common carp. Anim. Blood Group Biochem. Genet., 10, 141-149 (1979).

18) Y. Kosaka, Y. Fujio, and R. Suzuki: Genetic characteristics of races and colonies in Cyprinus carpio. Suisanikusyu, 5, 22-26 (1980) (in Japanese).

19) K. Sumantadinata and N. Taniguchi: Comparison of electrophoretic allele frequencies and genetic variability of common carp stocks from Indonesia and Japan. Aquaculture, 88, 263-271. (1990).

20) N. Taniguchi, M. Takagi, and S. Matsumoto: Genetic evaluation of quantitative and qualitative traits of hatchery stocks for aquaculture in red sea bream. Bull. Natl. Res. Inst. Aquacult., Suppl. 3, 35-41 (1997). 